\title{
Effects of Puerarin on Cardiac Differentiation and Ventricular Specialization of Murine Embryonic Stem Cells
}

\author{
Ying Cheng ${ }^{\mathrm{a}}$ Lu Wang ${ }^{\mathrm{a}}$ Ming Tang ${ }^{\mathrm{a}}$ Mengmeng Yin ${ }^{\mathrm{a}}$ Yurong Cui ${ }^{\mathrm{a}}$ Huamin \\ Liang $^{a}$ Yuanlong Song ${ }^{a}$ Xinwu Hu ${ }^{a}$ Hongyan Luo ${ }^{a}$ Ying Gao Jiayu Wang ${ }^{a}$ \\ Jürgen Hescheler ${ }^{b}$ Jiaoya $\mathrm{Xi}^{\mathrm{a}}$ \\ aDepartment of Physiology and Chinese-German Stem Cell Center, Tongji Medical College, \\ Huazhong University of Science and Technology, The Key Laboratory for Drug Target Researches \\ and Pharmacodynamic Evaluation of Hubei Province, Wuhan, China; 'bnstitute for Neurophysiology, \\ University of Cologne, Cologne, Germany
}

\section{Key Words}

Embryonic stem cells $\bullet$ Differentiation $\bullet$ Puerarin $\bullet$ Cardiomyocytes $\bullet$ Ventricle

\begin{abstract}
Aims: It is important to screen and identify chemical compounds to improve the efficiency of cardiac differentiation and specialization of embryonic stem (ES) cells. The objective of this study was to investigate the effect of puerarin, a natural phytoestrogen, on the in vitro cardiac differentiation and ventricular specialization of murine ES cells. Methods: Cardiac differentiation of murine ES cells was performed by embryoid body (EB)-based differentiation method. Quantitative RT-PCR, flow cytometry and immunofluorescence were employed to identify cardiomyocytes (CMs) derived from murine ES cells (mES-CMs). Patch clamp was used to study the electrophysiological properties of CMs. Results: We found that continuous puerarin treatment significantly increased the population of ES-CMs which express typical cardiac markers and are electrophysiological intact. Puerarin treatment shifted the cardiac phenotype from pacemaker-like cells to ventricular-like cells, which were Mlc2v-positive and present typical ventricular-like AP. Puerarin up-regulated transcripts involved in cardiac differentiation and ventricular specialization of ES cells. Conclusion: Our results suggest that puerarin promotes cardiac differentiation, and significantly enhances the specialization of $\mathrm{mES}$ cells into ventricular-like CMs. Puerarin may be used to increase the yield of ventricular $\mathrm{mES}-\mathrm{CMs}$ during in vitro differentiation.
\end{abstract}




\section{Cellular Physiology and Biochemistry}

Cell Physiol Biochem 2013;32:789-800

\begin{tabular}{l|l}
\hline DOI: $10.1159 / 000354480$ & (c) 2013 S. Karger AG, Basel
\end{tabular}

Published onlıne: September 20, 2013

www.karger.com/cpb

\section{Introduction}

Currently, cardiomyocytes (CMs) derived from embryonic stem (ES) cells (ES-CMs) or from induced pluripotent stem cells generated by the reprogramming of somatic cells represent the most promising cell sources to treat incurable cardiac diseases [1]. These pluripotent stem cell-derived CMs have been proven to possess all electrophysiological properties of typical cardiac cell [2]. Since myocardium infarction high frequently takes place in the ventricles but not the atriums, it is crucial to drive the differentiation of pluripotent stem cells into ventricular-like CMs to restore the mechanical function of injured ventricles. However, pluripotent stem cell-derived CMs are the mixture of pacemaker-, ventricular-, and atrial-like cells [3]. Therefore, screening and identifying chemical compounds that induce high efficiency cardiac differentiation and ventricular specialization of pluripotent stem cells is one of major steps toward a cell-mediated replacement therapy.

It has been shown that multiple signaling events are involved in the cardiogenesis of ES cells, including the transforming growth factor-beta (TGF $\beta$ ), bone morphogenetic protein (BMP) and Wnt signaling pathways [4]. So far, proteins from TGF $\beta$, BMP, and Wnt families [46], cytokines [7], natural or synthetic chemical compounds [3, 8-11]; and several transgenic ES cell systems [12] have been applied to selectively enhance the efficiency of cardiac differentiation from ES cells. Among these reports, retinoic acid and transgenic ES cell system are highlighted by their effects on ventricular specialization of ES cells. However, the disadvantages of these methods must be carefully considered. The multiple potent biological effects of cytokines might lead to unexpected side effects, and the safety of transgenic ES cells is questionable. Therefore, nature, economical and safe chemical compound such as traditional Chinese medicine might be more advantageous for protection or differentiation of working myocytes.

Puerarin [7-hydroxy-3-(4-hydroxyphenyl)-1-benzopyran-4-one 8-( $\beta$-DGlucopyranoside)] is the main isoflavone glycoside found in the herb radix pueraria or pueraria lobata (Willd.), which has been used in traditional Chinese medicine for thousands of years [13]. It has been demonstrated that puerarin has beneficial and protective effects on cardiovascular diseases, including unstable angina [14], acute myocardial infarction [15] and myocardial reperfusion injury [16]. It has been shown that puerarin promotes the in vitro osteoblasts differentiation in osteoblast-like UMR106 cells [17] and induces adipocyte differentiation of 3T3-L1 preadipocytes [18]. However, little is known about the pharmacological effects of puerarin on the cardiac differentiation of pluripotent stem cells.

In the present study, we investigated the effect of puerarin on the in vitro cardiac differentiation and ventricular specialization of murine ES cells. Our findings suggest that continuous application of puerarin increases the yield of functional ventricular CMs derived from murine ES cells. This study describes a new insight into the various biological effects of puerarin on cardiac differentiation of pluripotent stem cells.

\section{Materials and Methods}

\section{Cell culture and differentiation}

Undifferentiated murine ES cells from line D3 (CRL-1934, ATCC, USA) were grown on mouse embryonic fibroblasts inactivated by mitomycin $\mathrm{C}$ treatment (Kyowa Hakko Kogy) in propagation medium composed of Dulbecco's modified Eagle's medium supplemented with 15\% fetal bovine serum (FBS), 100 units/ $\mathrm{mL}$ penicillin-streptomycin, $1 \%$ non-essential amino acids (NEAA), $2 \mathrm{mmol} / \mathrm{L}$ L-glutamine, $0.1 \mathrm{mmol} / \mathrm{L}$ $\beta$-mercaptoethanol, and $1000 \mathrm{IU} / \mathrm{mL}$ leukemia inhibitory factor (ESGRO, Chemicon International). The differentiation of ES cells was induced by the generation of embryoid bodies (EBs) using the hanging drop method as previously described [11] with differentiation culture medium composed of Iscove's modified Dulbecco's medium (GIBCO), 20\% FBS, $0.1 \mathrm{mmol} / \mathrm{L} \beta$-mercaptoethanol, 1\% NEAA, 2 mmol/L L-glutamine, 100 units/mL penicillin-streptomycin. Puerarin $(1 \mu \mathrm{mol} / \mathrm{L}, 10 \mu \mathrm{mol} / \mathrm{L}, 100 \mu \mathrm{mol} / \mathrm{L}, 1000 \mu \mathrm{mol} / \mathrm{L}$, Drug Biology Product Examination Bureau, Beijing, China) was added from day 0 to day 16. EBs that were cultured 
Cheng et al.: Puerarin and Ventricular Specialization

Table 1. Primers for RT-PCR analysis. F: forward and R: reverse

\begin{tabular}{|c|c|c|c|c|}
\hline Gene & Primer sequence (forward/reverse) & $\begin{array}{l}\mathrm{Ta} \\
\left({ }^{\circ} \mathrm{C}\right)\end{array}$ & No. of cycles & $\begin{array}{l}\text { Product } \\
\text { size (bp) }\end{array}$ \\
\hline$\alpha-\mathrm{MHC}$ & $\begin{array}{l}\text { F: ACCTGGGCAAGTCTAACAAC } \\
\text { R:CTGGATTCTGGTGATGATACG }\end{array}$ & 58 & 30 & 704 \\
\hline GATA4 & $\begin{array}{l}\text { F: TCTCACTATGGGCACAGCAG } \\
\text { R:GCGATGTCTGAGTGACAGGA }\end{array}$ & 55 & 35 & 136 \\
\hline Nkx2.5 & $\begin{array}{l}\text { F: CAAGTGCTCTCCTGCTTTCC } \\
\text { R:GGCTTTGTCCAGCTCCACT }\end{array}$ & 55 & 35 & 137 \\
\hline Mef2c & $\begin{array}{l}\text { F: GGCCATGGTACACCGAGTACAACGAGC } \\
\text { R:GGGGATCCCTGTGTTACCTGCACTTGG }\end{array}$ & 63 & 30 & 381 \\
\hline Mlc2v & $\begin{array}{l}\text { F: TGTGGGTCACCTGAGGCTGTGGTTCAG } \\
\text { R:GAAGGCTGACTATGTCCGGGAGATGC }\end{array}$ & 63 & 35 & 189 \\
\hline $\mathrm{HCN} 4$ & $\begin{array}{l}\text { F: GCTGGTTTGTGGTAGATTTCA } \\
\text { R:AAACATCTTGCCTTGGTAGC }\end{array}$ & 55 & 35 & 674 \\
\hline Tbx5 & $\begin{array}{l}\text { F: CACAGCCCCTTCAGCAGCGAGAC } \\
\text { R:AGGGGCCCCGAGGTGAAATGAG }\end{array}$ & 63 & 30 & 495 \\
\hline TGF $\beta 1$ & $\begin{array}{l}\text { F: GCAACATGTGGAACTCTACCAGAA } \\
\text { R:GACGTCAAAAGACAGCCACTCA }\end{array}$ & 55 & 35 & 106 \\
\hline TGF $\beta 2$ & $\begin{array}{l}\text { F: ATGGATGGCTTA AGG AGTTTGA } \\
\text { R:AGATTGCCACTG ATT CCA AGTT }\end{array}$ & 57 & 35 & 203 \\
\hline TGF $\beta 3$ & $\begin{array}{l}\text { F: GCTCTTCCAGATACTTCGAC } \\
\text { R:AGCAGTTCTCCTCCAGGTTG }\end{array}$ & 55 & 35 & 442 \\
\hline Wnt3a & $\begin{array}{l}\text { F: ATTGAATTTGGAGGAATGGT } \\
\text { R:CTTGAAGTACGTGTAACGTG }\end{array}$ & 54 & 40 & 318 \\
\hline Wnt11 & $\begin{array}{l}\text { F: GCCATGAAGGCCTGCCGTAG } \\
\text { R:GATGGTGTGACTGATGGTGG }\end{array}$ & 65 & 40 & 153 \\
\hline BMP2 & $\begin{array}{l}\text { F: GAATCAGAACACAAGTCAGT } \\
\text { R:GTTTGTGTTTGGCTTGACGC }\end{array}$ & 55 & 30 & 272 \\
\hline BMP4 & $\begin{array}{l}\text { F: TGTGAGGAGTTTCCATCACG } \\
\text { R:CAGCGAAGGACTGCAGGGCT }\end{array}$ & 55 & 30 & 323 \\
\hline GAPDH & $\begin{array}{l}\text { F: GTGTTCCTACCCCCAATGTG } \\
\text { R:CTTGCTCAGTGTCCTTGC;TG }\end{array}$ & 55 & 35 & 349 \\
\hline
\end{tabular}

with differentiation medium containing $0.05 \%$ dimethyl sulfoxide (Sigma) served as negative controls. Medium was changed every two days. Rhythmically beating areas in EBs were considered to be beating CMs and were defined as the marker of successful cardiac differentiation. EBs containing rhythmically beating areas were labeled as beating EBs. The number of beating EBs was counted from day 7 to day 16 of differentiation. For the observation of EB-size, EBs were kept and in suspension cultivation till day 16 and images were taken every day. All cultivation medium and other substances for cell culture were purchased from Gibco BRL if not otherwise indicated.

\section{Quantification of cardiac differentiation by flow cytometry}

EBs at day 12 of differentiation were dissociated to single cell suspensions by the addition of $0.05 \%$ Trypsin-EDTA (GIBCO) at $37{ }^{\circ} \mathrm{C}$ for $3 \mathrm{~min}$ and then $1 \mathrm{mg} / \mathrm{mL}$ collagenase B (Roche) at $37{ }^{\circ} \mathrm{C}$ for $20 \mathrm{~min}$. One million cells per sample were fixed and permeabilized according to the protocol supplied by the manufacturer (BD Biosciences Pharmingen). Mouse IgG anti- $\alpha$-sarcomeric-actinin antibody (A7811, 1:100, Sigma) served as the primary antibodies. The secondary antibody was sheep anti-mouse R-Phycoerythrinconjugated IgG (P8547, 1:100, Sigma). Cells stained with primary isotype control antibody and secondary fluorescence-conjugated antibody served as a control. The percentage of $\alpha$-actinin-positive cells was obtained by subtracting negative control after gating out the dead cells. Three independent experiments were performed with the Aria Cell Sorter (BD Biosciences).

\section{Semi-quantitative RT-PCR and quantitative real-time PCR analysis}

Total RNA was extracted from EBs using TRIzol Reagent (Invitrogen) according to the manufacturer's instructions at day 4, 6, 8, 10 and 16 of differentiation. Reverse transcription was performed with ReverTra Ace reverse transcriptase (Toyobo, Japan). The primers, annealing temperature, product size, and number of RT-PCR cycles are depicted in Table 1.

Quantitative real-time PCR (qRT-PCR) was performed with $1.6 \mu \mathrm{L}$ of cDNA template added to SYBR Premix Ex Taq (TaKaRa Biotechnology) containing specific primers on the MxPR03000 Real-Time PCR machine (Stratagene Technology Company), as described before [11]. The primers and product size are depicted in Table 2. The expression of each gene was defined from the threshold cycle (Ct). After 


\section{Cellular Physiology and Biochemistry}

Cell Physiol Biochem 2013;32:789-800

\begin{tabular}{l|l}
\hline DOI: $10.1159 / 000354480$ & (C) 2013 S. Karger AG, Basel
\end{tabular}

Publisned online: september 20, $2013 \quad$ www.karger.com/cpb

Cheng et al.: Puerarin and Ventricular Specialization normalization with reference to expression of the housekeeping gene GAPDH, relative expression levels were calculated by using the $2^{-\Delta \Delta \mathrm{Ct}}$ method and normalized by control group.

\section{Electrophysiological recordings}

CMs isolated from EBs at day 16 of differentiation were plated on sterile, $0.1 \%$ gelatin-coated glass coverslips and incubated at $37^{\circ} \mathrm{C}$ for 24 to $36 \mathrm{~h}$ before the experiments. The action potentials (APs) of the ES-CMs were recorded from spontaneously beating ES-CMs using the whole-cell patch clamp under current clamp mode as described previously [11]. The data were acquired and analyzed off-line using the Clampfit 9.0 analysis software (Axon Instruments). The APs were
Table 2. Primers quantitative real-time PCR analysis. F: forward and R: reverse

\begin{tabular}{|c|c|c|}
\hline Gene & Primer sequence (forward/reverse) & $\begin{array}{l}\text { Product size } \\
\quad \text { (bp) }\end{array}$ \\
\hline$\alpha-\mathrm{MHC}$ & $\begin{array}{l}\text { F: GATTTCTCCAACCCAGCTGCGCC } \\
\text { R:CGGATGTCAAAGGGCCGGGTC }\end{array}$ & 201 \\
\hline Mlc2v & $\begin{array}{l}\text { F: TCCCGAGGGCAAAGGGTCACT } \\
\text { R:CGTCAGGGGGAAAGGCTGCG }\end{array}$ & 116 \\
\hline $\mathrm{HCN} 4$ & $\begin{array}{l}\text { F: CCCGCCTCATTCGATACATTCAT } \\
\text { R: GAGGGCGTAGGAATACTGCTTC }\end{array}$ & 233 \\
\hline Mef2c & $\begin{array}{l}\text { F: TGTCCAGCCATAACAGTTTGG } \\
\text { R: GGTTGCCGTATCCATTCCCT }\end{array}$ & 210 \\
\hline Tbx5 & $\begin{array}{l}\text { F: TGGCTGAAGTTCCACGAAGTG } \\
\text { R: TTTGGGATTAAGGCCAGTCAC }\end{array}$ & 187 \\
\hline TGF $\beta 1$ & $\begin{array}{l}\text { F: CCGCAACAACGCCATCTATG } \\
\text { R: CCCGAATGTCTGACGTATTGAAG }\end{array}$ & 80 \\
\hline TGF $\beta 2$ & $\begin{array}{l}\text { F: ATGGATGGCTTA AGGAGTTTGA } \\
\text { R: AGATTGCCACTGATT CCAAGTT }\end{array}$ & 203 \\
\hline TGF $\beta 3$ & $\begin{array}{l}\text { F: GGACTTCGGCCACATCAAGAA } \\
\text { R: TAGGGGACGTGGGTCATCAC }\end{array}$ & 111 \\
\hline GAPDH & $\begin{array}{l}\text { F: TGACCACAGTCCATGCCATC } \\
\text { R:GACGGACACATTGGGGGTAG }\end{array}$ & 204 \\
\hline
\end{tabular}

classified using previously described criteria $[3,11]$. To detect the adrenergic and muscarinic regulation of CMs, isoproterenol (Iso, $1 \mu \mathrm{M}$; Sigma) or carbachol (Cch, $1 \mu \mathrm{M}$; Sigma) was added to the Tyrode's solution.

\section{Immunofluorescent staining}

Cells were fixed with $4 \%$ paraformaldehyde, and permeabilized with $1 \%$ Triton X-100 for 5 min. After being treated with $5 \%$ bovine serum albumin, specimens were incubated with monoclonal antisarcomeric-actinin (1:100, Sigma) or polyclonal rabbit anti-ventricular-specific gene myosin light chain- $2 \mathrm{v}$ (Mlc-2v, 1:100, Abcam). The fluorescent antibody was Anti-Mouse-Ig-phycoerythrin for (1:100, Sigma) or FITC-conjugated goat anti-rabbit IgG (1:100, Proteintech Group). Nuclei were stained with DAPI (Vector Laboratories). Images were taken from randomly chosen field. The percentage of Mlc-2v-positive cells was calculated by dividing the number of Mlc- $2 \mathrm{v}$ double positive cells to the total number of cells and normalized by control group. The counting was performed independently by three operators.

\section{Statistical analysis}

Unless otherwise stated, the results were given as the mean \pm SEM for at least three independent experiments. The significance of differences between the means was evaluated by student's unpaired t-test or ANOVA. A value of $\mathrm{P}<0.05$ was used as the criterion for statistical significance.

\section{Results}

Puerarin enhances the percentage of ES-CMs in beating EBs

The percentage of beating EBs was significantly increased at day 12 of differentiation by application of high concentration $(100 \mu \mathrm{mol} / \mathrm{L}$ and $1000 \mu \mathrm{mol} / \mathrm{L})$ but not low concentration of puerarin $(1 \mu \mathrm{mol} / \mathrm{L}$ and $10 \mu \mathrm{mol} / \mathrm{L})$ (Fig. 1A). $100 \mu \mathrm{mol} / \mathrm{L}$ of puerarin was chosen for the following experiments. The percentage of beating EBs progressively increased and reached a plateau from day 12 to day 16 in both groups, but was significantly higher in the puerarin treated group during the same period (Fig. 1B). As differentiation progressed, the strength of contraction of beating areas increased and peaked on day 16. At day 16 of differentiation, $81.4 \pm 3.5 \%$ of EBs treated with puerarin exhibited spontaneous beating compared to $60.7 \pm 7.5 \%$ in control group ( $n=5$ independent experiment, $p=0.0380$ ). The diameters of EBs in both groups progressively increased and were comparable during the suspension culture period (Fig. 1C).

The cardiac specific genes $\alpha$-myosin heavy chain $(\alpha-\mathrm{MHC})$ was up-regulated at differentiation day 6 and 8 in puerarin treated EBs (Fig. 1D). ES-CMs were further identified 


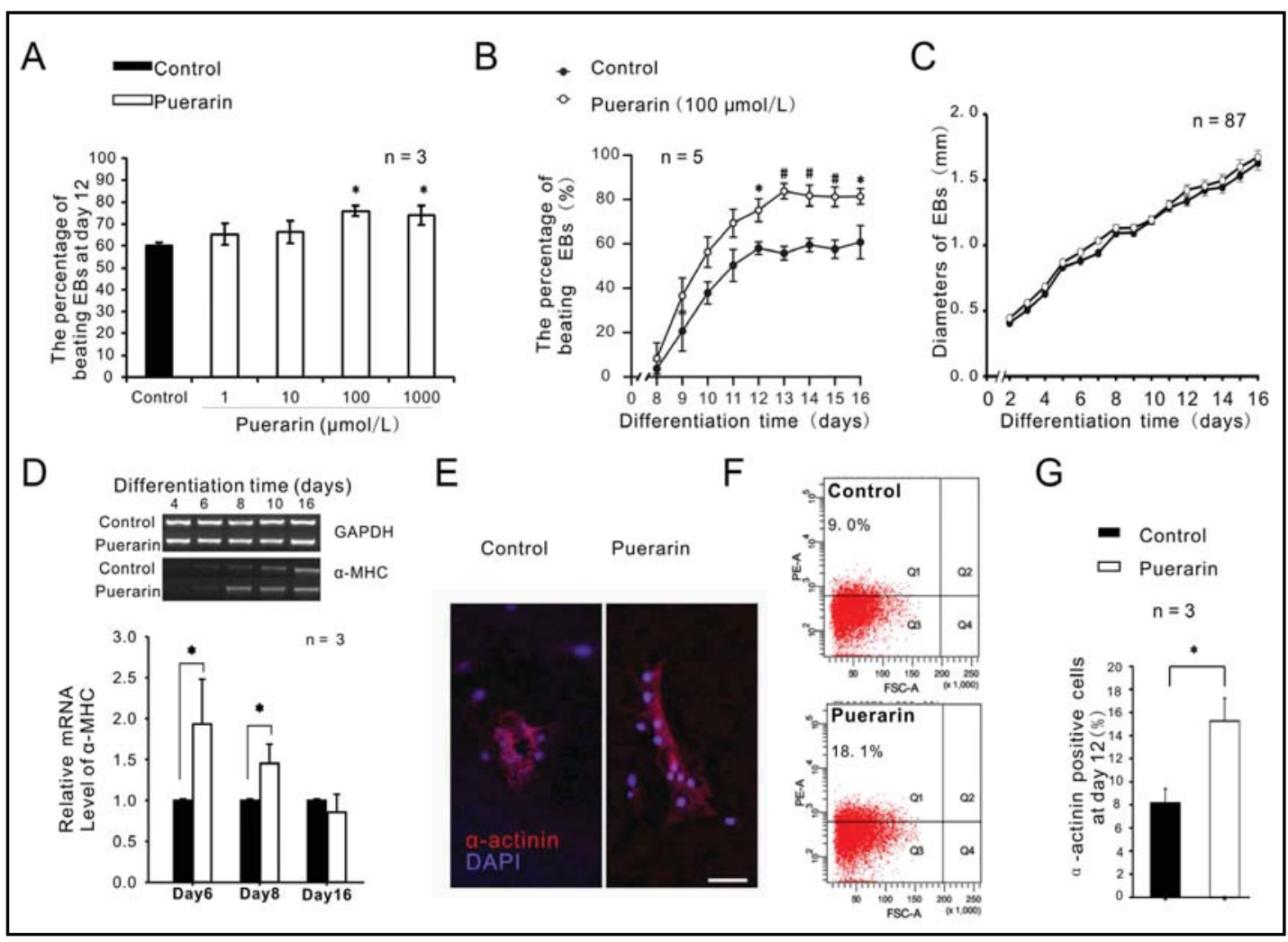

Fig. 1. Puerarin enhances the percentage of ES-CMs in beating EBs. A. Effects of different doses of puerain on the percentage of beating EBs at day 12 of differentiation $(n=3)$. B. Percentage of beating EBs during differentiation $(n=5)$. C. Statistics analysis of diameters of EBs without $(n=87)$ or with puerarin treatment $(n=87)$. No significant difference could be found. D. RT-PCR and real-time PCR analysis of cardiac $\alpha$-MHC transcript level at day 6, 8, and 16 of differentiation. The data were from three independent experiments. E. Immunofluorescent staining of cardiac $\alpha$-actinin (red) in control group (left) and puerarin treated group (right) at day 12. Nuclei were stained with DAPI (blue). Scale bar $=50 \mu \mathrm{m}$. F. The representative data of flow cytometric analysis at day 12 of differentiation. $\alpha$-actinin-positive cells are shown in quadrant 1 (Q1). G. Flow cytometric analysis shows the percentage of $\alpha$-actinin-positive cells in the total population of cells of EBs derived from the ES cells at day 12 of differentiation $(n=3)$. All Data are presented as mean \pm SEM. *, $\mathrm{p}<0.05$ vs. control group. \#, $\mathrm{p}<0.01$ vs. control group.

as cardiac $\alpha$-actinin-positive cells (Fig. 1E). Flow cytometric quantification of the cardiac $\alpha$-actinin-positive cells revealed that the percentage of $\alpha$-actinin-positive cells was significantly higher in the puerarin treatment group $(15.3 \pm 1.9 \%)$ than in the control group $(8.2 \pm 1.2 \%)(n=3, p=0.0349)$ at day 12 (Fig. $1 \mathrm{~F}$ and $\mathrm{G})$. These data suggest that puerarin enhances the percentage of ES-CMs in beating EBs.

CMs derived from puerarin-treated ES cells are electrophysiological intact and their phenotypes are shifted from pacemaker-like cells to ventricular-like cells

We next investigated the electrophysiological properties of puerarin induced ESCMs by patch-clamp. The APs of 16-day-old ES-CMs in both groups were recorded and characterized using patch-clamp analysis. Based on the criteria described previously [3, $11]$, the APs were classified as ventricular-like, atrial-like or pacemaker-like. Ventricle-like APs were characterized by a rapid up stroke velocity (about $50 \mathrm{v} / \mathrm{s}$ ), a longer duration (the action potential duration measured from the maximal depolarization to $90 \%$ repolarization (ADP90) is around $110 \mathrm{~ms}$ ), a larger amplitude (around 95mV) and a pronounced plateau 


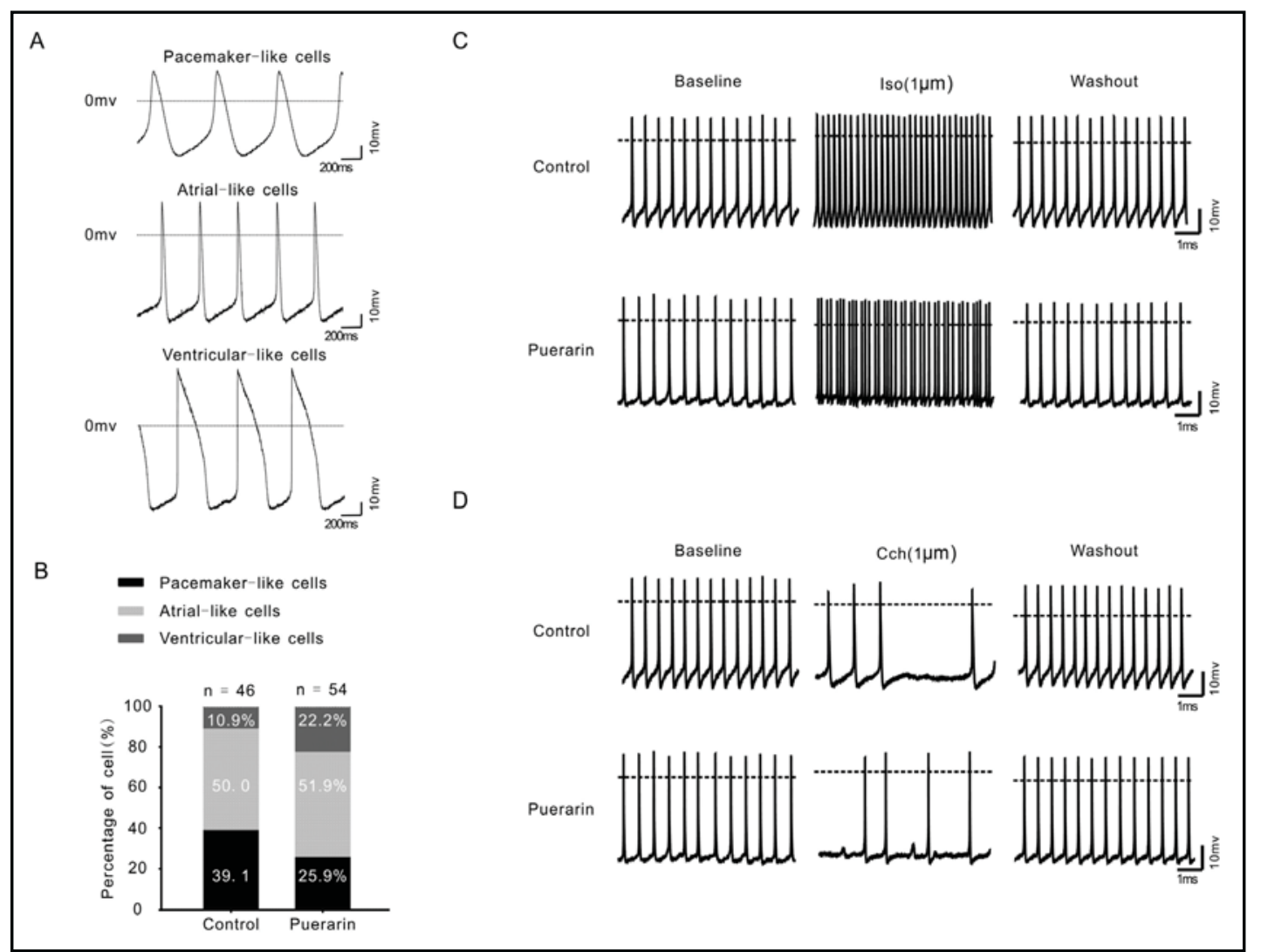

Fig. 2. CMs derived from puerarin-treated ES cells are electrophysiological intact A. Three major types of APs were discriminated in the puerarin treatment ES-CMs: pacemaker-like, atrial-like and ventricular-like APs. B. The relative percentage of the AP types recorded from the control and puerarin treatment cultures. 54 of puerarin-induced ES-CMs and 46 of control ES-CMs from 6 independent differentiations were randomly selected and recorded. C and D. Typical reponse of mES-CMs in the control group (upper) and the puerarin treated group (low) to Iso (C) and Cch (D).

\begin{tabular}{|c|c|c|c|c|c|c|}
\hline \multirow[b]{2}{*}{ Parameters } & \multicolumn{3}{|c|}{ Control $(n=46)$} & \multirow[b]{2}{*}{$\begin{array}{c}\text { p-like } \\
(\mathrm{n}=14)\end{array}$} & \multicolumn{2}{|c|}{ Puerarin $(n=54)$} \\
\hline & $\begin{array}{l}\text { p-like } \\
(n=18)\end{array}$ & $\begin{array}{c}\text { a-like } \\
(n=23)\end{array}$ & $\begin{array}{l}\text { v-like } \\
(n=5)\end{array}$ & & $\begin{array}{l}\text { a-like } \\
(n=28)\end{array}$ & $\begin{array}{c}\text { v-like } \\
(\mathrm{n}=12)\end{array}$ \\
\hline APD90 (ms) & $75.3 \pm 5.6$ & $100.9 \pm 7.4$ & $110.5 \pm 12.5$ & $105.0 \pm 3.1^{*}$ & $102.8 \pm 5.3$ & $136.4 \pm 21.4$ \\
\hline $\mathrm{APA}(\mathrm{mv})$ & $66.2 \pm 2.8$ & $77.3 \pm 3.3$ & $98.0 \pm 1.7$ & $71.4 \pm 2.5$ & $79.6 \pm 2.7$ & $95.6 \pm 3.0$ \\
\hline MDP (mv) & $-52.4 \pm 2.1$ & $-55.9 \pm 2.8$ & $-60.1 \pm 1.5$ & $-53.0 \pm 2.1$ & $-55.3 \pm 1.4$ & $-60.4 \pm 1.3$ \\
\hline
\end{tabular}

Table 3. Electrophysiological properties of puerarin-untreated (control) and puerarin-treated ES cell-derived cardiomyocytes at day 16 of differentiation. Data were expressed as mean \pm SE. The electrophysiological parameters were used for the identification of the different cardiac cell types: APD90 is the action potential duration measured from the maximal depolarization to $90 \%$ repolarization in ms, APA is action potential amplitude and MDP is maximum diastolic potential. No statistical difference in the electrophysiological parameters between puerarin-treated and puerarin-untreated cells could be observed, with the exception of the ADP90 in pacemaker-like cells. *, p<0.05 vs. control

phase. Cells with ventricle-like APs displayed a more negative maximum diastolic potential (MDP, around - 60mV) compared to other cell types. Atrial-like APs were characterized by their short duration (ADP90 around 100ms), combined with a fast up stroke velocity (about $25 \mathrm{v} / \mathrm{s}$ ) and a short plateau phase. Pacemaker-like APs were characterized by a prominent diastolic depolarization, a slow upstroke (about $8 \mathrm{v} / \mathrm{s}$ ) and a smaller amplitude (about 
A

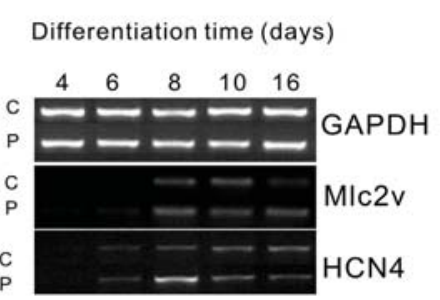

B

- Control $\square$ Puerarin

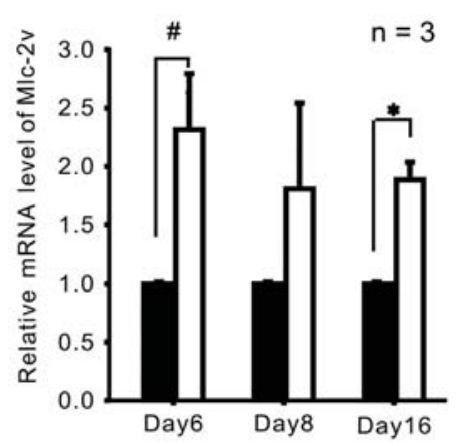

C

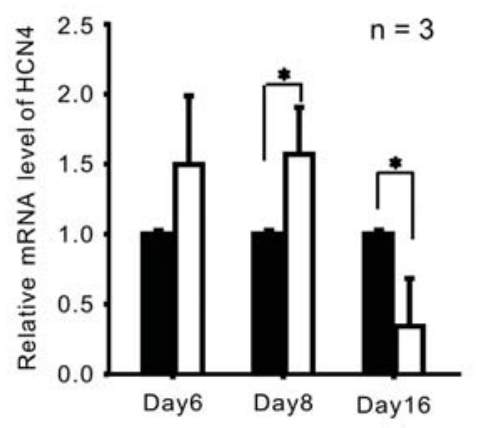

D
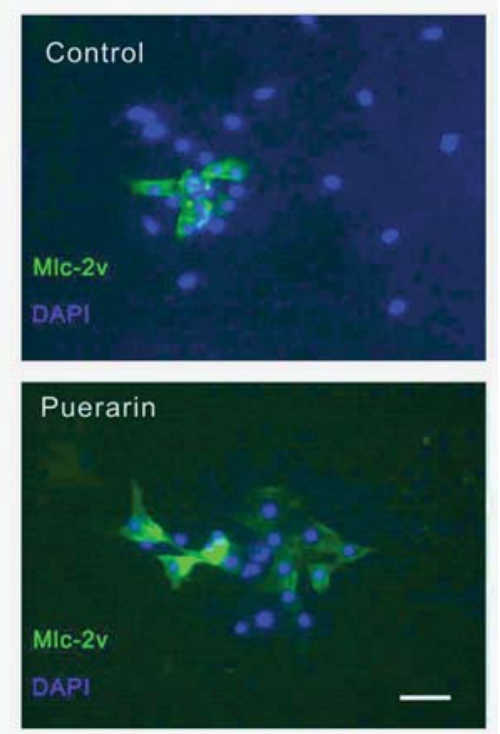

E

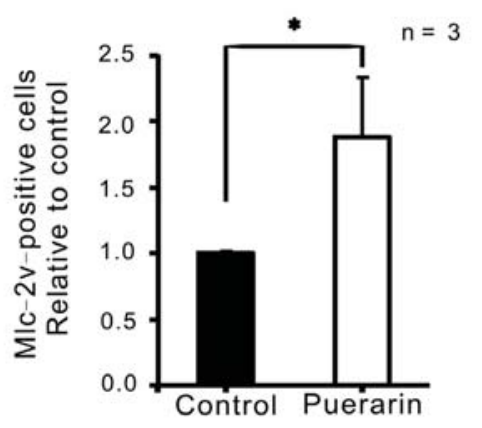

Fig. 3. Puerarin shifts the phenotype of ES-CMs from pacemaker-like cells to ventricular-like cells. A. RTPCR analysis of the mRNA levels of ventricular specific Mlc2v and pacemaker channel gene HCN4 in the EBs during differentiation. B. Real-time PCR analysis of Mlc2v mRNA levels in the EBs at days 6, 8 and 16 of differentiation. $\mathrm{n}=3$ independent experiments. C. Real-time PCR analysis of HCN4 revealed that puerarin up-regulated HCN4 transcript at day 8 but down-regulated it at day 16. n = 3 independent experiments. D. Representative immunofluorescent staining of Mlc2v (green) in control group (upper) and puerarin treated group (low) at day 16. Nuclei were stained with DAPI (blue). Scale bar $=50 \mu \mathrm{m}$. E. The statistic analysis of normalized percentage of Mlc2v-positive cells by control group. The data are showed as mean \pm SEM, $*$, p < 0.05 . \#, $\mathrm{p}<0.01$.

$66 \mathrm{mV}$ ). The MDP of pacemaker-like APs was about $-52 \mathrm{mV}$. Typical APs of three phenotypes of CMs could be recorded in both the control group and the puerarin treatment group (Fig. $2 \mathrm{~A}$ ). Interestingly, puerarin treatment doubled the percentage of ventricular-like cells, with a paralleled decrease of pacemaker-like cells. There was no effect on the percentage of atriallike cells (Fig. 2B). In 54 of randomly selected puerarin-induced ES-CMs (from 6 independent differentiation experiments), $22.2 \%$ of cells presented ventricular-like APs, $51.9 \%$ atriallike APs, and $25.9 \%$ pacemaker-like APs. In the control group, only $10.9 \%$ of ES-CMs (5 of 46) presented ventricular-like APs, $50.0 \%$ (23 of 46) atrial-like APs, and 39.1\% (18 of 46) pacemaker-like APs. The ES-CMs in both groups had typical and comparable responses to Iso $(1 \mu \mathrm{M})$ (Fig. $2 \mathrm{C})$ and Cch $(1 \mu \mathrm{M})$ (Fig. 2D), demonstrating their well established $\beta$-adrenergic 


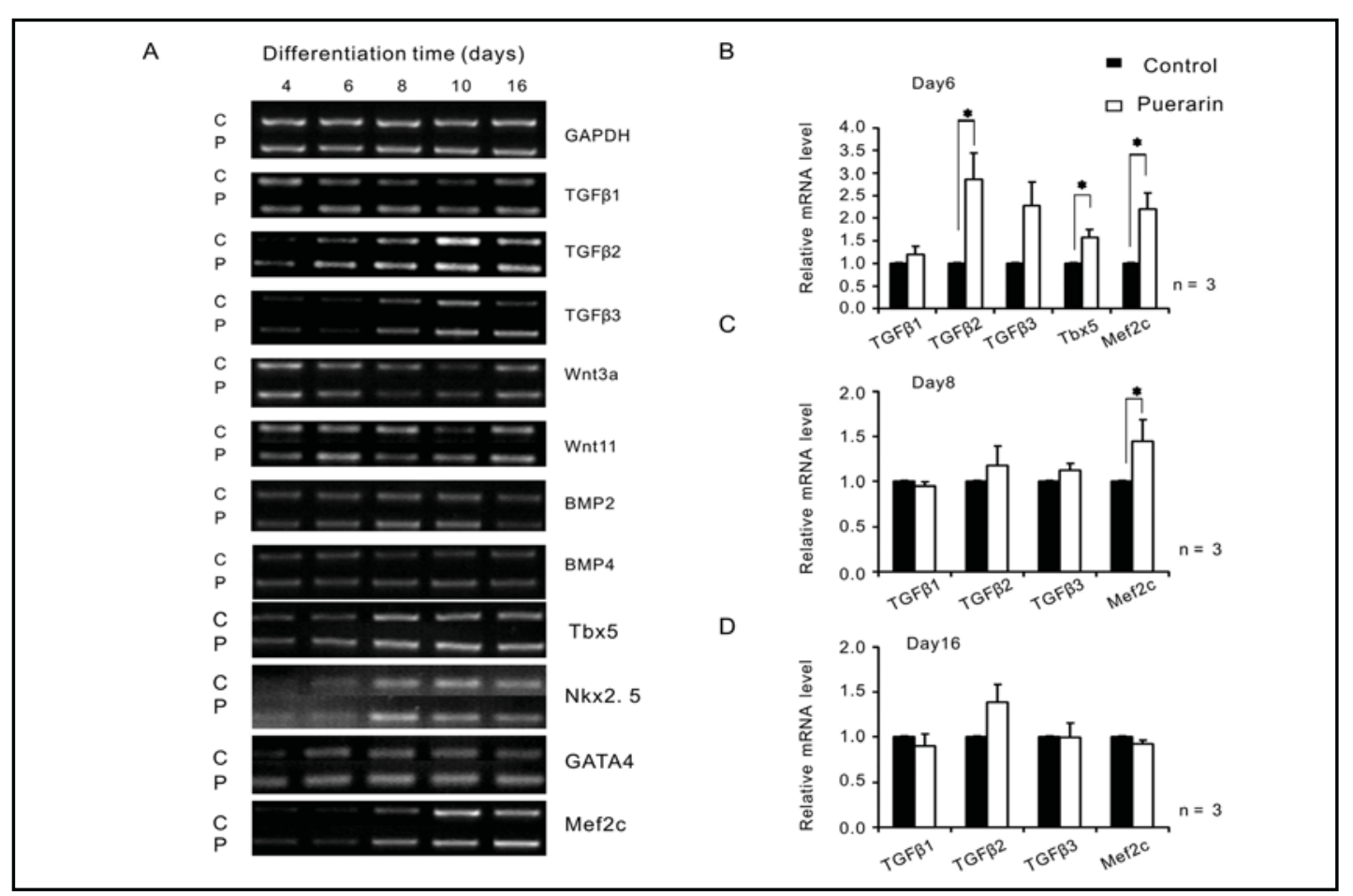

Fig. 4. The effect of puerarin on the expression of cardiogenesis signaling patheways and cardiac transcription factors. A: Representative data from RT-PCR for TGF $1 / \beta 2 / \beta 3$, Wnt3a/11, BMP2/4 and indicated cardiac transcription factors without (upper, $\mathrm{C}=$ control group) or with puerarin treatment (lower, $\mathrm{P}=$ puerarin treatment group). B. Real-time PCR analysis of TGF $\beta 1 / \beta 2 / \beta 3$, Tbx5 and Mef2c transcript levels in the EBs at day 6 of differentiation. C. Real-time PCR analysis revealed that the expression level of Mef2c was upregulated by puerarin at day 8 of differentiation. D. Real-time PCR analysis showed that puerarin did not affect the expression levels of TGF $\beta 1 / \beta 2 / \beta 3$ and Mef2c at day 16 of differentiation. The data are shown as means \pm SEM; $n=3$ independent experiments, ${ }^{*}, \mathrm{p}<0.05$ vs. control group.

receptor and muscarinic acetylcholine receptor signaling pathways. Moreover, as shown in Table 3, the parameters of AP were unaffected by puerarin treatment, except for the APD90. The pacemaker-like ES-CMs had a significantly longer APD90 in puerarin treated group (105.0 $\pm 13.1 \mathrm{~ms}, \mathrm{n}=14$ ) compared with control group $(75.3 \pm 5.6 \mathrm{~ms}, \mathrm{n}=18 ; \mathrm{p}<0.05)$.

We next studied the effect of puerarin on the expression levels of the Mlc-2v, and pacemaker channel gene potassium/sodium hyperpolarization-activated cyclic nucleotidegated channel 4 (HCN4) by RT-PCR and real-time PCR. Consistent with our patch clamp results, we found that puerarin treatment doubled the transcript level of ventricular-specific Mlc-2 $v$ at day 6 and day 16 of differentiation, but decreased that of pacemaker channel gene HCN4 at day 16 (Fig. 3A, B and C). Moreover, semi-quantitative analysis of immunofluorescent staining showed that Mlc-2v-positive cells at day 16 were almost doubled by puerarin treatment (Fig. 3D and E).

These data demonstrate that puerarin shifts the cardiac phenotype from pacemakerlike cells to ventricular-like cells, and facilitates ventricular specialization.

Puerarin up-regulates transcripts involved in cardiac differentiation and ventricular specialization of ES cells

The cardiac differentiation of ES cells is regulated by TGF- $\beta$, BMP and Wnt signaling pathways. These signaling pathways interact with each other by affecting downstream cardiac transcription factors including NK 2 transcription factor related locus 5 (Nkx2.5), GATA binding protein 4 (GATA4), T-box 5 (Tbx5) and myocyte enhancer factor 2c (Mef2c) 


\section{Cellular Physiology and Biochemistry}

Cell Physiol Biochem 2013;32:789-800

\begin{tabular}{l|l}
\hline DOI: $10.1159 / 000354480$ & (C) 2013 S. Karger AG, Basel
\end{tabular}

www.karger.com/cpb

Cheng et al.: Puerarin and Ventricular Specialization

[4-6]. Therefore, we next focused on signaling pathways that regulate cardiac differentiation and downstream cardiac transcription factors by RT-PCR and qRT-PCR.

Puerarin treatment significantly affected the mRNA levels of TGF $\beta$ family at day 6 of differentiation, but almost had no effects on Wnts and BMPs (Fig. 4A). QRT-PCR further confirmed that puerarin treatment significantly increased the mRNA level of TGF $\beta 2$ at day 6, but not TGF $\beta 1$ and TGF $\beta 3$ (Fig. 4B, C and D). Transcripts of the downstream cardiac transcription factor Tbx5 and Mef2c were up-regulated by puerarin at day 6 and day 8 of differentiation, respectively (Fig. 4A, B and C). GATA4 and Nkx2.5 showed no remarkable differences in transcript abundance between puerarin and control variants (Fig. 4A).

\section{Discussion}

Puerarin has been reported to possess antihypeglycemic, antihypercholesterolemia and antioxidant activities [19-21]. Key findings of the present study are: (1) continuous puerarin treatment significantly increases population of ES-CMs which express typical cardiac markers and are electrophysiological intact; (2) puerarin treatment shifts the cardiac phenotype from pacemaker-like cells to ventricular-like cells, which are Mlc2v-positive and present typical ventricular-like AP; (3) puerarin up-regulates transcripts involved in cardiac differentiation and ventricular specialization of ES cells.

So far, the effects of reported natural or synthetic cardiomyogenesis enhancers are quite different due to different culture conditions between lab to lab, different observation timepoints, and different cell lines. In the present study, a 20\% increase in the percentage of beating EBs by puerarin treatment was observed from day 12 to day 16 of differentiation, which is comparable with effects of retinoic acid [3] and neuregulin 1 [7] on the D3 murine ES cells. However, the percentage of beating EBs is widely considered as a very crude index of the efficiency of in vitro cardiomyogenesis. Alternatively, the percentage of cardiac specific marker-positive CMs by flow cytometry analysis is a fairer criterion to demonstrate the effect of cardiomyogenesis agents. In our system, puerarin treatment harvested about 7\% more $\alpha$-actinin-positive CMs derived from D3 murine ES cells at day 12 of differentiation compared with control group. Comparable with our report, Yee-Ki Lee et al. found that ouabain facilitates cardiac differentiation with a 7\% increase in the percentage of cardiac troponin I (cTnl)-positve CMs derived from D3 murine ES cells at day 9 of differentiation [9]. However, Wiese et al. reported that suramin has no effect on the percentage of cTnI-positive CMs derived from R1 murine ES cells at day 9 of differentiation, but increases the number of cTnI-positive CMs by 5.6 fold at day 22 [10]. Previously our group reported that baicalin treatment has no effect on the percentage of beating EBs and $\alpha$-actinin-positive CMs derived from D3 murine ES cells at day 10 and 16 of differentiation. Nevertheless, baicalin results in a $70 \%$ increase in the percentage of beating EBs and a $10 \%$ increase in the percentage of $\alpha$-actinin-positive CMs at day 20 of differentiation by inducing cell death of non-CMs in EBs [11]. With regard to synthetic chemical compounds, the reporters employed the quantification of the expressed EGFP from CMs derived from transgenic $\alpha \mathrm{MHC} \mathrm{Cl} 23$ murine ES cells to estimate their effects on cardiac differentiation. In their study, synthetic chemical compounds result in a 50 to $80 \%$ increase in cardiomyogenesis compared to untreated cells at day 14 of differentiation [8], which seems to be more efficient than puerarin.

Both human and murine pluripotent stem cells differentiate and develop into a heterogeneous population of CMs in vitro $[3,10]$. Ventricular myocytes, atrial myocytes and pacemaker cells are different from each other on both morphological, molecular, and functional properties [22]. Mlc2v is highly expressed and spatially restricted to the ventricular portion of the murine heart tube and the outflow tract, with no detectable expression in the atrial or sinus venosus regions [23, 24]. Therefore, Mlc2v has been used as a molecular marker for the process of ventricular specialization during in vitro cardiogenesis [3]. In contrast, HCN4 is highly expressed in sinus node and is required for mature cardiac pacemaker activity [25]. Interestingly, in the present study, we found that puerarin treatment 


\section{Cellular Physiology and Biochemistry}

Cell Physiol Biochem 2013;32:789-800

\begin{tabular}{l|l}
\hline DOI: $10.1159 / 000354480$ & (c) 2013 S. Karger AG, Basel
\end{tabular}

www.karger.com/cpb

Cheng et al.: Puerarin and Ventricular Specialization

shifts the cardiac phenotype from pacemaker-like cells to ventricular-like cells, which are Mlc2v-positive and present typical ventricular-like AP.

Numerous signaling events are involved in the cardiogenesis of ES cells [26]. These signaling pathways regulate cardiac differentiation by affecting downstream transcription factors and structural genes [27]. In vivo, development and formation of the chambered heart are determined by cooperation and interaction of many transcription factors and structural genes [22]. Tbx5 belongs to the Tbx superfamily and is necessary for proper septal [28], cardiac conduction system and ventricular chamber [27] formation. It specifies the identity of the left ventricle through tight interactions the heart-specific factors Nkx2.5, GATA4 and Mef2c [29]. Mef2c is another fundamental gene in ventricular differentiation [30]. It has been shown that functional interaction between Tbx5 and Mef2c is crucial in ventricular differentiation [31].

In the present study, we observed that puerarin up-regulated transcript level of TGF $\beta 2$ at differentiation day 6 , but had no effect on expressions of TGF $\beta 1$, TGF $\beta 3$, Wnts and BMPs. Consistent with our results, previous report demonstrates that TGF $\beta 2$,but not TGF $\beta 1$ or TGF 3 , promotes cardiac myocyte differentiation from murine CGR8 ES cells [32] and enhances cytoprotective factors released from ES cells [33]. We only found that puerarin affected expression of Tbx5 and Mef2c, but not Nkx2.5 and GATA4. These results indicate that puerarin might affect cardiac differentiation via TGF $\beta$ signaling pathway. Up-regulation of TGF $\beta 2$, Tbx5 and Mef2c transcripts might play roles in puerarin-induced cardiac differentiation and ventricular specialization. Further studies are suggested to better understand the role of TGF $\beta 2$ and TGF $\beta$ signaling pathway in puerarin-induced ventricular specialization of ES cells.

In addition to transcriptional regulation, posttranscriptional control by micro RNA (miRs) also quantitatively affects the differentiation [34] and ventricular specification [35] in vitro and in vivo [36]. It has been shown that miR-1, miR-133, and miR-499 play crucial roles in cardiogenesis. MiR-1 and miR-133 are cardiac and skeletal muscle specific miRs, which are transcriptionally controlled by MyoD and Mef2c [37, 38]. MiR-1 promotes mesoderm formation from ES cells and promotes further differentiation into cardiac muscle progenitors [34]. In vivo, lacking miR-1 results in ventricular septal defects and cardiac dysfunction in mice [36]. MiR-499 has been proven to be crucial to cardiac differentiation and ventricular specification of human ES cells [35, 39]. Recently, it is reported that miR-27 plays a role in mouse ventricular maturation by modulating Mef2c expression [40]. Collectively, we hypothesize that these miRs might be involved in puerarin-induced cardiac differentiation and ventricular specification. Further studies of miRs in our system are needed.

This study provides the first report of the effect of puerarin on the cardiac differentiation of ES cells. Our results suggest that long-term puerarin treatment promotes cardiogenesis and enhances the specialization of mES cells into ventricular-like cells. Additional work is needed to further confirm its effects on human pluripotent stem cells.

\section{Acknowledgements}

We gratefully acknowledge all the other members of Department of Physiology and Chinese-German Stem Cell Center. This study was supported by the National Natural Science Foundation of China (No.31100828 and No.30700262), the Natural Science Foundation of Hubei Province (2011CDB363), the Project-sponsored by SRF for ROCS Jiaoya Xi, SEM, the Fundamental Research Funds for the Central Universities (HUST: 2011QN211, 2012ZHYX019 and 2013TS145), the Science Foundation of HUST for Jiaoya Xi, and the Ph.D Program Foundation of SEM (20070487012) for Ming Tang. 


\section{Cellular Physiology and Biochemistry}

Cell Physiol Biochem 2013;32:789-800

\begin{tabular}{l|l}
\hline DOI: $10.1159 / 000354480$ & (c) 2013 S. Karger AG, Basel
\end{tabular}

Publisned onlıne: September 20, $2013 \quad$ www.karger.com/cpb

Cheng et al.: Puerarin and Ventricular Specialization

\section{References}

$>1$ Yu J, Vodyanik MA, Smuga-Otto K, Antosiewicz-Bourget J, Frane JL, Tian S, Nie J, Jonsdottir GA, Ruotti V, Stewart R, Slukvin, II, Thomson JA: Induced pluripotent stem cell lines derived from human somatic cells. Science 2007;318:1917-1920.

-2 Pfannkuche K, Liang H, Hannes T, Xi J, Fatima A, Nguemo F, Matzkies M, Wernig M, Jaenisch R, Pillekamp F, Halbach M, Schunkert H, Saric T, Hescheler J, Reppel M: Cardiac myocytes derived from murine reprogrammed fibroblasts: Intact hormonal regulation, cardiac ion channel expression and development of contractility. Cell Physiol Biochem 2009;24:73-86.

-3 Wobus AM, Kaomei G, Shan J, Wellner MC, Rohwedel J, Ji G, Fleischmann B, Katus HA, Hescheler J, Franz WM: Retinoic acid accelerates embryonic stem cell-derived cardiac differentiation and enhances development of ventricular cardiomyocytes. J Mol Cell Cardiol 1997;29:1525-1539.

4 Pandur P, Lasche M, Eisenberg LM, Kuhl M: Wnt-11 activation of a non-canonical wnt signalling pathway is required for cardiogenesis. Nature 2002;418:636-641.

5 Schultheiss TM, Burch JB, Lassar AB: A role for bone morphogenetic proteins in the induction of cardiac myogenesis. Genes Dev 1997;11:451-462.

6 Watabe T, Miyazono K: Roles of tgf-beta family signaling in stem cell renewal and differentiation. Cell Res 2009;19:103-115.

7 Sun M, Yan X, Bian Y, Caggiano AO, Morgan JP: Improving murine embryonic stem cell differentiation into cardiomyocytes with neuregulin1:Differential expression of microrna. Am J Physiol Cell Physiol 2011;301:C21-30.

8 Berkessel A, Seelig B, Schwengberg S, Hescheler J, Sachinidis A: Chemically induced cardiomyogenesis of mouse embryonic stem cells. Chembiochem 2010;11:208-217.

\$ Lee YK, Ng KM, Lai WH, Man C, Lieu DK, Lau CP, Tse HF, Siu CW: Ouabain facilitates cardiac differentiation of mouse embryonic stem cells through erk1/2 pathway. Acta Pharmacol Sin 2011;32:52-61.

10 Wiese C, Nikolova T, Zahanich I, Sulzbacher S, Fuchs J, Yamanaka S, Graf E, Ravens U, Boheler KR, Wobus AM: Differentiation induction of mouse embryonic stem cells into sinus node-like cells by suramin. Int J Cardiol 2011;147:95-111.

11 Tang M, Yin M, Tang M, Liang H, Yu C, Hu X, Luo H, Baudis B, Haustein M, Khalil M, Saric T, Hescheler J, $\mathrm{Xi}$ J: Baicalin maintains late-stage functional cardiomyocytes in embryoid bodies derived from murine embryonic stem cells. Cell Physiol Biochem 2013;32:86-99.

-12 Muller M, Fleischmann BK, Selbert S, Ji GJ, Endl E, Middeler G, Muller OJ, Schlenke P, Frese S, Wobus AM, Hescheler J, Katus HA, Franz WM: Selection of ventricular-like cardiomyocytes from es cells in vitro. FASEB J 2000;14:2540-2548.

13 Qicheng F: Some current study and research approaches relating to the use of plants in the traditional chinese medicine. J Ethnopharmacol 1980;2:57-63.

14 Zhao Z, Yang X, Zhang Y: [clinical study of puerarin in treatment of patients with unstable angina]. Zhongguo Zhong Xi Yi Jie He Za Zhi 1998;18:282-284.

15 Xiao LZ, Huang Z, Ma SC, Zen Z, Luo B, Lin X, Xu X: [study on the effect and mechanism of puerarin on the size of infarction in patients with acute myocardial infarction]. Zhongguo Zhong Xi Yi Jie He Za Zhi 2004;24:790-792.

-16 Fan LL, Sun LH, Li J, Yue XH, Yu HX, Wang SY: The protective effect of puerarin against myocardial reperfusion injury. Study on cardiac function. Chin Med J (Engl) 1992;105:11-17.

17 Tiyasatkulkovit W, Charoenphandhu N, Wongdee K, Thongbunchoo J, Krishnamra N, Malaivijitnond S: Upregulation of osteoblastic differentiation marker mrna expression in osteoblast-like umr106 cells by puerarin and phytoestrogens from pueraria mirifica. Phytomedicine 2012;19:1147-1155.

18 Lee OH, Seo DH, Park CS, Kim YC: Puerarin enhances adipocyte differentiation, adiponectin expression, and antioxidant response in 3t3-11 cells. Biofactors 2010;36:459-467.

19 Hsu FL, Liu IM, Kuo DH, Chen WC, Su HC, Cheng JT: Antihyperglycemic effect of puerarin in streptozotocininduced diabetic rats. J Nat Prod 2003;66:788-792.

20 Yan LP, Chan SW, Chan AS, Chen SL, Ma XJ, Xu HX: Puerarin decreases serum total cholesterol and enhances thoracic aorta endothelial nitric oxide synthase expression in diet-induced hypercholesterolemic rats. Life Sci 2006;79:324-330. 


\section{Cellular Physiology and Biochemistry}

Cell Physiol Biochem 2013;32:789-800

\begin{tabular}{l|l}
\hline DOI: $10.1159 / 000354480$ & (c) 2013 S. Karger AG, Basel
\end{tabular}

Cheng et al.: Puerarin and Ventricular Specialization

-21 Guerra MC, Speroni E, Broccoli M, Cangini M, Pasini P, Minghett A, Crespi-Perellino N, Mirasoli M, CantelliForti G, Paolini M: Comparison between chinese medical herb pueraria lobata crude extract and its main isoflavone puerarin antioxidant properties and effects on rat liver cyp-catalysed drug metabolism. Life Sci 2000;67:2997-3006.

22 Ng SY, Wong CK, Tsang SY: Differential gene expressions in atrial and ventricular myocytes: Insights into the road of applying embryonic stem cell-derived cardiomyocytes for future therapies. Am J Physiol Cell Physiol 2010;299:C1234-1249.

-23 Franz WM, Breves D, Klingel K, Brem G, Hofschneider PH, Kandolf R: Heart-specific targeting of firefly luciferase by the myosin light chain-2 promoter and developmental regulation in transgenic mice. Circ Res 1993;73:629-638.

-24 O'Brien TX, Lee KJ, Chien KR: Positional specification of ventricular myosin light chain 2 expression in the primitive murine heart tube. Proc Natl Acad Sci U S A 1993;90:5157-5161.

25 Stieber J, Herrmann S, Feil S, Loster J, Feil R, Biel M, Hofmann F, Ludwig A: The hyperpolarization-activated channel hcn4 is required for the generation of pacemaker action potentials in the embryonic heart. Proc Natl Acad Sci U S A 2003;100:15235-15240.

26 MacLellan WR, Schneider MD: Genetic dissection of cardiac growth control pathways. Annu Rev Physiol 2000;62:289-319.

27 Olson EN: Gene regulatory networks in the evolution and development of the heart. Science 2006;313:1922-1927.

28 Horb ME, Thomsen GH: Tbx5 is essential for heart development. Development 1999;126:1739-1751.

-29 Takeuchi JK, Ohgi M, Koshiba-Takeuchi K, Shiratori H, Sakaki I, Ogura K, Saijoh Y, Ogura T: Tbx5 specifies the left/right ventricles and ventricular septum position during cardiogenesis. Development 2003;130:59535964.

-30 Vong L, Bi W, O'Connor-Halligan KE, Li C, Cserjesi P, Schwarz JJ: Mef2c is required for the normal allocation of cells between the ventricular and sinoatrial precursors of the primary heart field. Dev Dyn 2006;235:1809-1821.

-31 Ghosh TK, Song FF, Packham EA, Buxton S, Robinson TE, Ronksley J, Self T, Bonser AJ, Brook JD: Physical interaction between tbx5 and mef2c is required for early heart development. Mol Cell Biol 2009;29:22052218.

-32 Singla DK, Sun B: Transforming growth factor-beta2 enhances differentiation of cardiac myocytes from embryonic stem cells. Biochem Biophys Res Commun 2005;332:135-141.

33 Singla DK, Singla RD, Lamm S, Glass C: Tgf-\{beta\}2 treatment enhances cytoprotective factors released from embryonic stem cells and inhibits apoptosis in infarcted myocardium. Am J Physiol Heart Circ Physiol 2011;300:H1442-1450.

-34 Ivey KN, Muth A, Arnold J, King FW, Yeh RF, Fish JE, Hsiao EC, Schwartz RJ, Conklin BR, Bernstein HS, Srivastava D: Microrna regulation of cell lineages in mouse and human embryonic stem cells. Cell Stem Cell 2008;2:219-229.

35 Fu JD, Rushing SN, Lieu DK, Chan CW, Kong CW, Geng L, Wilson KD, Chiamvimonvat N, Boheler KR, Wu JC, Keller G, Hajjar RJ, Li RA: Distinct roles of microrna-1 and -499 in ventricular specification and functional maturation of human embryonic stem cell-derived cardiomyocytes. PLoS One 2011;6:e27417.

-36 Zhao Y, Ransom JF, Li A, Vedantham V, von Drehle M, Muth AN, Tsuchihashi T, McManus MT, Schwartz RJ, Srivastava D: Dysregulation of cardiogenesis, cardiac conduction, and cell cycle in mice lacking mirna-1-2. Cell 2007;129:303-317.

-37 Kwon C, Han Z, Olson EN, Srivastava D: Microrna1 influences cardiac differentiation in drosophila and regulates notch signaling. Proc Natl Acad Sci U S A 2005;102:18986-18991.

-38 Rao PK, Kumar RM, Farkhondeh M, Baskerville S, Lodish HF: Myogenic factors that regulate expression of muscle-specific micrornas. Proc Natl Acad Sci U S A 2006;103:8721-8726.

-39 Wilson KD, Hu S, Venkatasubrahmanyam S, Fu JD, Sun N, Abilez OJ, Baugh JJ, Jia F, Ghosh Z, Li RA, Butte AJ, Wu JC: Dynamic microrna expression programs during cardiac differentiation of human embryonic stem cells: Role for mir-499. Circ Cardiovasc Genet 2010;3:426-435.

-40 Chinchilla A, Lozano E, Daimi H, Esteban FJ, Crist C, Aranega AE, Franco D: Microrna profiling during mouse ventricular maturation: A role for mir-27 modulating mef2c expression. Cardiovasc Res 2011;89:98-108. 